\title{
Cisplatin and ultra-violet-C synergistically down-regulate receptor tyrosine kinases in human colorectal cancer cells
}

\author{
Junji Kawaguchi', Seiji Adachi 1,2,3*, Ichiro Yasuda', Takahiro Yamauchi ${ }^{1}$, Masanori Nakashima ${ }^{1}$, Tomohiko Ohno ${ }^{1}$,
} Masahito Shimizu', Takashi Yoshioka², Masahiko Itani ${ }^{2}$, Osamu Kozawa ${ }^{2}$ and Hisataka Moriwaki ${ }^{1}$

\begin{abstract}
Background: Platinum-containing anti-cancer drugs such as cisplatin are widely used for patients with various types of cancers, however, resistance to cisplatin is observed in some cases. Whereas we have recently reported that high dose UV-C $\left(200 \mathrm{~J} / \mathrm{m}^{2}\right)$ induces colorectal cancer cell proliferation by desensitization of EGFR, which leads oncogenic signaling in these cells, in this study we investigated the combination effect of low dose cisplatin $(10 \mu \mathrm{M})$ and low dose UV-C $\left(10 \mathrm{~J} / \mathrm{m}^{2}\right)$ on cell growth and apoptosis in several human colorectal cancer cells, SW480, DLD-1, HT29 and HCT116.

Results: The combination inhibited cell cycle and colony formation, while either cisplatin or UV-C alone had little effect. The combination also induced apoptosis in these cells. In addition, the combination caused the downregulation of EGFR and HER2. Moreover, UV-C alone caused the transient internalization of the EGFR, but with time EGFR recycled back to the cell surface, while cisplatin did not affect its localization. Surprisingly, the combination caused persistent internalization of the EGFR, which results in the lasting downregulation of the EGFR.

Conclusions: The combination of low dose cisplatin and low dose UV-C synergistically exerted anti-cancer effect by down-regulating RTK, such as EGFR and HER2. These findings may provide a novel strategy for the treatment of patients with colorectal cancer.
\end{abstract}

Keywords: Cisplatin, UV-C, EGFR, HER2, Down-regulation, Cell growth inhibition

\section{Introduction}

Among the receptor tyrosine kinases (RTKs), the ErbB family, such as epidermal growth factor receptor (EGFR; ErbB1) or human epidermal growth factor receptor-2 (HER2; ErbB2) plays a pivotal role in regulating a number of cellular processes including cell proliferation, survival and migration [1], and dysregulation of EGFR activity leads to tumorgenesis [2]. Mechanisms leading to oncogenic signaling behind EGFR are thought as follows: 1) increased EGFR levels, 2) autocrine and/or paracrine growth factor loops, 3) heterodimerization with other EGFR family members and cross-talk with

\footnotetext{
* Correspondence: seijiadachi0123@gmail.com

'Departments of Gastroenterology, Gifu University Graduate School of Medicine, Gifu 501-1194, Japan

${ }^{2}$ Departments of Pharmacology, Gifu University Graduate School of Medicine, Gifu 501-1194, Japan

Full list of author information is available at the end of the article
}

heterologous receptor systems, 4) defective receptor downregulation, and 5) activating mutations [3].

We have previously reported that the blockade of EGF stimulation significantly suppressed colorectal cancer cell growth, suggesting that the EGFR pathway plays an important role in proliferation of these cells [4]. Thus, EGFR downregulation is a critical target for therapy against colorectal cancer that is highly dependent on EGFR. As for HER2, their expression has been first reported to be amplified in breast cancer [5]. Since clinical and experimental evidences show a role for overexpression of the HER2 protein in the progression of human breast, ovarian, non-small cell lung [6] and colorectal cancer [7], HER2 may be a candidate target for receptor-targeted therapeutics.

Cis-diamminedichloroplatinum (CDDP) or cisplatin is one of the most effective DNA-damaging anti-tumor

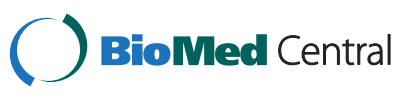


agent and is used for the treatment of various human cancers [8-10]. However, resistance to cisplatin arises in some cases and many compounds combined with platinum-based drugs are now ongoing clinical trials [11]. Increasing evidences show that cisplatin directly influences EGFR signaling. Cisplatin reportedly induces EGFR internalization [12], phosphorylation at Thr1045 mediated via a ubiquitin ligase, $\mathrm{c}-\mathrm{Cbl}$ [13] and phosphorylation at Thr669, at a site which is phosphorylated by p38 MAPK [14], while activation of stress-activated protein kinase/c-Jun-N-terminal kinase or p38 MAPK by cisplatin has been reported to promote apoptotic cell death [15]. In addition, in many studies researchers have used cisplatin at relatively higher doses $(30 \mu \mathrm{M}$ or more), which is impractical in vivo.

Ultra-violet (UV) radiation is divided into three bands: UV-A (320-400 nm), UV-B (280-320 nm) and UV-C (200-280 nm). Most of the UV-C and approximately $90 \%$ of UV-B are absorbed while passing through the atmospheric layers. UV-A and UV-B are recognized harmful for humans, while UV-C is used for studying DNA damage and cellular DNA repair process [16]. So far, the possibility of application rather for treatment of human cancer has been demonstrated $[17,18]$. In a series of papers, Petersen et al have investigated the photophysical consequences of illuminating the aromatic residues of proteins with UV-C [19-25]. In particular, they demonstrated that $280 \mathrm{~nm}$ UV illumination of aromatic residues in proteins causes the disruption of nearby disulphide bridges, where EGFR are excessively populated, leading to the suppression of the proliferative potential in human cancer cell lines [17].

Whereas we recently reported the availability of UV-C alone $\left(30 \mathrm{~J} / \mathrm{m}^{2}\right.$ and more) in human colorectal cancer cells, in which we showed that UV-C can evade these cells from oncogenic stimulation of EGF by decreasing the EGFR protein level [26], we herein investigated the combination use of low dose cisplatin and low dose UV-C on cell growth in human colorectal cancer cells (SW480, HT29, DLD-1 and HCT116) and found that the combination has synergistic effect on cell growth inhibition by down-regulating receptor tyrosine kinases, such as EGFR and HER2.

\section{Results}

\section{Effects of cisplatin and/or UV-C on cell proliferation in human colorectal cancer cells}

Bromodeoxyuridine (BrdU) is a synthetic thymidine analog that gets incorporated into DNA during cell division. Therefore, the measurement of BrdU incorporation reflects the ability of cell growth. We first investigated the effects of cisplatin and/or UV-C on cell proliferation using BrdU. Whereas either $10 \mu \mathrm{M}$ of cisplatin or $10 \mathrm{~J} / \mathrm{m}^{2}$ of UV-C hardly affected BrdU incorporation in SW480 and DLD-1 cells (Figure 1A, lanes 2 and 3 , respectively), the combination caused a marked inhibition in BrdU incorporation (Figure 1A, lane 4 , respectively). While it has previously been reported that cisplatin induces cell cycle arrest at the G2-phase [27], cell cycle analysis using flow cytometry revealed that the combination of cisplatin and $\mathrm{UV}-\mathrm{C}$ increased the population at G2/M phases $(28.2 \pm 1.35 \%)$, compared with cisplatin $(21.9 \pm 0.68 \% ; \mathrm{p}=0.0014)$ or UV-C (15.2 $\pm 0.76 \% ; p=0.0004)$ (Figure 1B). Moreover, we examined the protein level of phospho-Rb and cyclin D1, both of which direct cells toward proliferation by controlling progression through the restriction point of cell cycle (Figure 2A) [28]. In SW480 cells, cisplatin by itself had little effect on phosphorylation level of $\mathrm{Rb}$. However, when the cells were first exposed to UV-C and then incubated in the presence of cisplatin, the protein level of phospho- $\mathrm{Rb}$ was decreased in a timedependent manner after $12 \mathrm{~h}$ (Figure 2). Since we have recently reported that $10 \mathrm{~J} / \mathrm{m}^{2}$ of UV-C did not cause the decrease in the protein level of $\mathrm{Rb}$ [26], these results suggest that the combination of cisplatin and UV-C exerts synergistic effect on the suppression of cell cycle. We also verified the combination effect in DLD-1, HT29 and HCT116, other human colorectal cancer cell lines (Figure 2).

\section{Effects of cisplatin and/or UV-C on colony formation in human colorectal cancer cells}

We next performed colony formation assay, which is a microbiology technique for studying the effectiveness of specific agents on the survival and proliferation of cells (Figure 2B) [29]. The combination synergistically suppressed colony formation of SW480 cells, although cisplatin or UV-C alone did to a lesser extent. Similarly, the combination synergistically decreased the number of colony formation in DLD-1 and HCT116 cells, whereas UV-C alone slightly affected them in these cells. As for HT29 cells, while cisplatin or UV-C alone has no effect, the combination synergistically suppressed colony formation. As a whole, these results suggest that the combination has cytocidal effects on several colorectal cancer cells.

\section{Effects of cisplatin and/or UV-C on the apoptosis in human colorectal cancer cells}

We next investigated the combination effect of cisplatin and UV-C on apoptosis by observing PARP cleavage, since PARP is a family of proteins involved in a number of cellular processes involving mainly DNA repair and programmed cell death, indicating cell apoptosis [30]. While cisplatin or UV-C alone had little effect on PARP, the combination caused PARP cleavage in SW480, DLD-1, HT29 and HCT116 cells (Figure 3A). 
(A) SW480

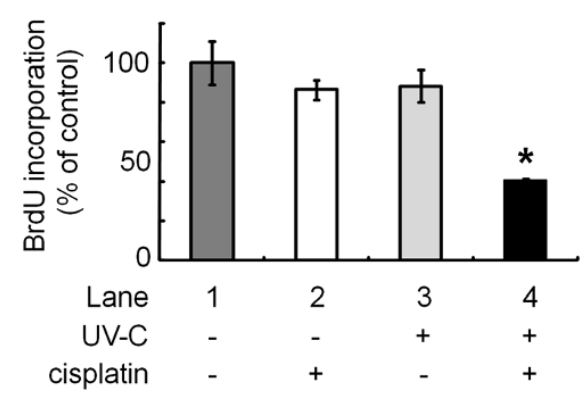

(B)

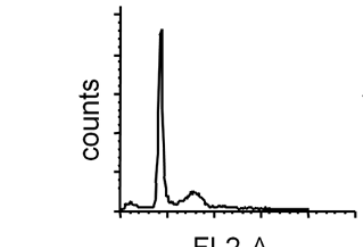

FL2-A

group

UV-C

cisplatin

1

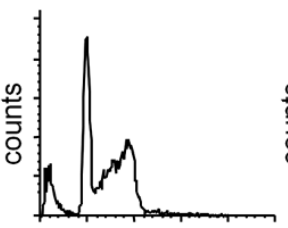

FL2-A

2

$-$

\section{DLD-1}

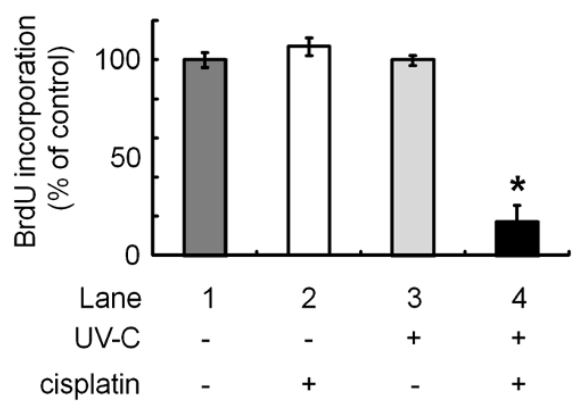

Figure 1 (A) Effects of cisplatin and/or UV-C on cell proliferation in human colorectal cancer cells. SW480 and DLD-1 cells were either exposed to $10 \mathrm{~J} / \mathrm{m}^{2} \mathrm{UV}-\mathrm{C}$ (lanes 3), treated with $10 \mu \mathrm{M}$ cisplatin (lanes 2), or received both (lanes 4). Twenty four $\mathrm{h}$ later, the measurement of $\mathrm{BrdU}$ incorporation was performed using cell proliferation ELISA (BrdU). Results are expressed as percentage of incorporation with 100\% representing that by untreated control cells (lanes 1). (B) SW480 cells were treated with $10 \mu \mathrm{M}$ cisplatin (group 2), $10 \mathrm{~J} / \mathrm{m}^{2} \mathrm{UV}-\mathrm{C}$ (group 3) or combination of $10 \mu \mathrm{M}$ cisplatin and $10 \mathrm{~J} / \mathrm{m}^{2} \mathrm{UV}-\mathrm{C}$ (group 4). The cells were then stained with propidium iodide (PI) to analyze progression of cell cycle. The distribution of cells in the apoptosis and each phase of cell cycle were calculated in each group. Bars designate SD of triplicate assay. The asterisks $\left(^{*}\right)$ indicate significant decrease $(p<0.05)$ as compared to the corresponding control, respectively.

While Hoechst33258 are used to stain DNA and easily detect such DNA fragments, we next examined the effect of combination of cisplatin and UV-C on DNA fragmentation utilizing this dye and found that the combination increased the number of Hoechst 33258positive apoptotic cells in SW480 and HT29 cells (Figure 3B), which are consistent with our results shown in Figure 3A.

\section{Effects of cisplatin and/or UV-C on the protein level of EGFR and HER2 in human colorectal cancer cells}

As described in Introduction, EGFR downregulation is the most prominent regulatory system in signal attenuation and involves the internalization and subsequent degradation of the activated receptor in the lysosomes. As well, HER2 is frequently overexpressed in colorectal cancer when compared with normal colonic mucosa, and the extent of overexpression seems to correlate with increasing disease stage and poorer patient survival [31]. Therefore, therapies that target the EGFR and/or HER2 may be effective in the chemoprevention and/or therapy of colorectal cancer [32]. Whereas we recently reported that EGFR signaling plays a critical role in proliferation of colorectal cancer cells [26], we next focused on the expression level of EGFR as well as HER2 in several colorectal cancer cells including SW480, DLD-1, HT29 and HCT116, since we observed that the combination use of cisplatin and UV-C synergistically exerts suppressive effect on cell proliferation and apoptosis (Figures 1 and 3). As depicted in Figure 4, $10 \mu \mathrm{M}$ cisplatin alone did not affect these levels even after a longer treatment in SW480 (Figure 4, lanes 1-4). As well, while UV-C at a dose over $30 \mathrm{~J} / \mathrm{m}^{2}$ caused a marked decrease in the EGFR protein level [26], in this study we observed that $10 \mathrm{~J} / \mathrm{m}^{2}$ of UV-C did not affect (Additional file 1). Interestingly, the combination use of $10 \mu \mathrm{M}$ cisplatin and $10 \mathrm{~J} / \mathrm{m}^{2} \mathrm{UV}-\mathrm{C}$ clearly induced the decrease in the protein levels of EGFR as well as HER2 in SW480 cells, which were appeared at $12 \mathrm{~h}$ after treatment with cisplatin and UV-C (Figure 4, lanes 5-8). Similar results were observed in other colorectal cancer cells, DLD-1, HT29 and HCT116. Together, the combination effect of cisplatin and UV-C on the suppression of cell growth seems to be due to the down-regulation of EGFR and/or HER2. 


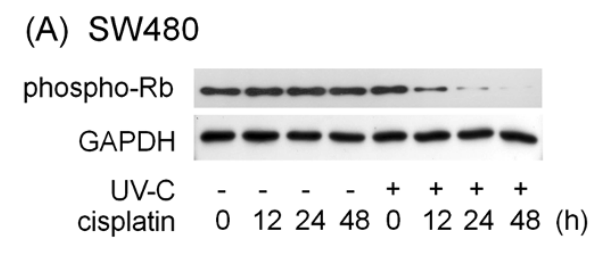

HT29

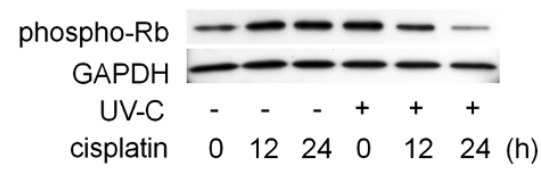

(B) SW480

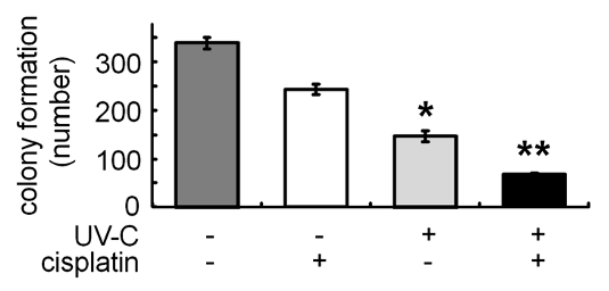

HT29

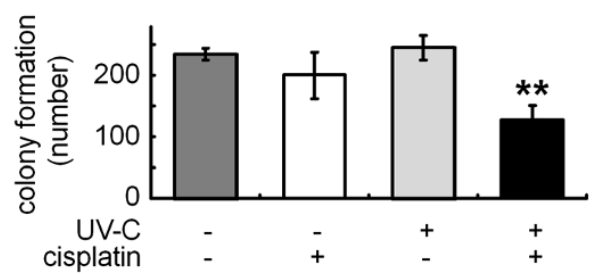

DLD-1

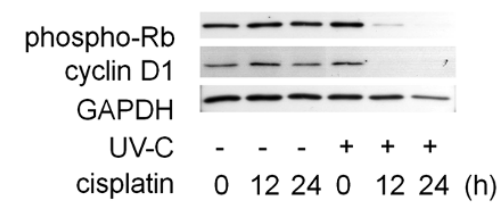

HCT116

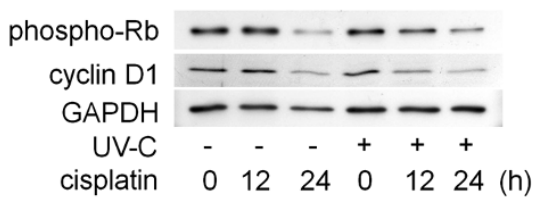

DLD-1

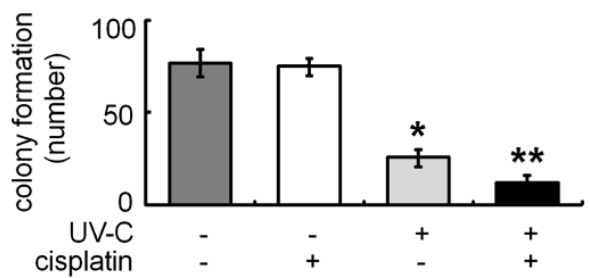

HCT116

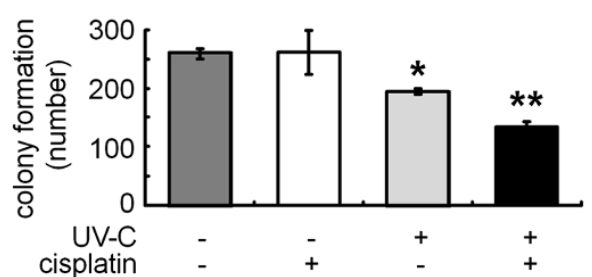

Figure 2 (A) Effects of cisplatin and/or UV-C on cell proliferation markers, phospho-Rb and cyclin D1 in human colorectal cancer cells. SW480, DLD-1, HT29 and HCT116 cells were first exposed to $10 \mathrm{~J} / \mathrm{m}^{2}$ of UV-C or not, and then treated with $10 \mu \mathrm{M}$ of cisplatin for the indicated periods. Protein extracts were harvested and examine by Western blotting using anti-phospho-Rb and anti-cyclin D1 antibodies. (B) Effects of cisplatin and/or UV-C on colony formation in SW480, DLD-1, HT29 and HCT116 human colorectal cancer cells. The attached human colorectal cancer cells were first exposed to the indicated doses UV-C (0 or $\left.10 \mathrm{~J} / \mathrm{m}^{2}\right)$, just after the aspiration of the growth medium. The cells were then incubated in normal growth media with/without $10 \mu \mathrm{M}$ cisplatin for $24 \mathrm{~h}$. After trypsinization, the counted cells $\left(3 \times 10^{3}\right)$ were re-seeded into new culture dishes and incubated for 7 days. The cells were then fixed with clonogenic reagent (see Materials and methods) and the average number of colony from 5 randomly chosen fields ( $x$ 20) were counted, respectively. Bars designate SD of triplicate assay. The asterisks (* and **) indicate significant decrease $(p<0.05)$ as compared to the control and UV-C alone, respectively.

\section{Effects of cisplatin and/or UV-C on the internalization of EGFR in SW480 cells}

It has previously been reported that UV irradiation $\left(100 \mathrm{~J} / \mathrm{m}^{2}\right)$ induces rapid and persistent internalization of EGFR [33]. As well, we have recently reported that UV$\mathrm{C}$ at a dose over $30 \mathrm{~J} / \mathrm{m}^{2}$ caused the internalization and subsequent down-regulation of the EGFR in SW480 cells [26]. In order to elucidate the mechanism underlying combination effect of cisplatin and UV-C, we next examined whether cisplatin $(10 \mu \mathrm{M})$ and/or UV-C $\left(10 \mathrm{~J} / \mathrm{m}^{2}\right)$ induces changes in the subcellular localization of
EGFR in SW480 cells. Whereas antibody-tagged EGFR remained on the cell surface (Figure 5A, panels 1, 6 and 11), $0.5 \mathrm{~h}$ incubation after the treatment of the cells with $\mathrm{UV}-\mathrm{C}$ alone $\left(10 \mathrm{~J} / \mathrm{m}^{2}\right)$ resulted in the distribution of the EGFR to cytosol beneath the plasma membrane, thus indicating that UV-C indeed induced the internalization of the EGFR (Figure 5A, panel 7). By contrast, cisplatin $(10 \mu \mathrm{M})$ by itself did not affect the localization of the EGFR (Figure 5A, panels 2-5). Interestingly, when the cells were first exposed to UV-C and then incubated in the absence of cisplatin for $6 \mathrm{~h}$ and more, the antibody- 
(A) SW480

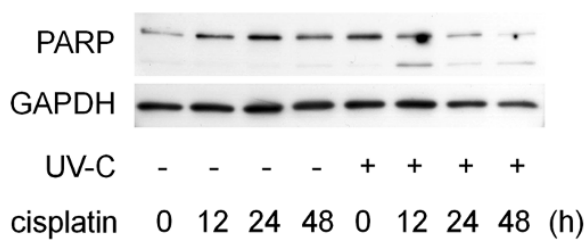

HT29

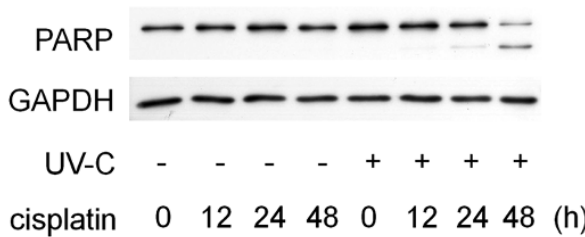

DLD-1

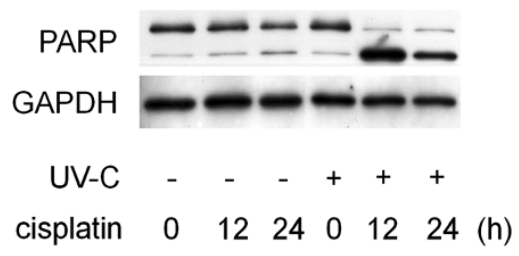

HCT116

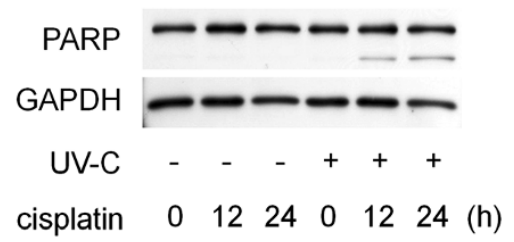

(B)

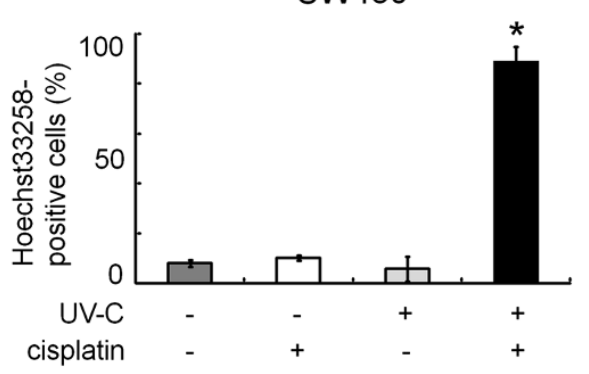

HT29

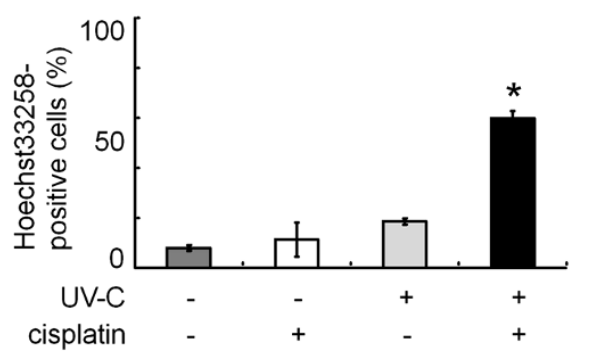

Figure 3 (A) Effects of cisplatin and/or UV-C on PARP cleavage and DNA fragmentation in human colorectal cancer cells. SW480, DLD-1, HT29 and HCT116 cells were first exposed to the indicated doses of UV-C $\left(0 \mathrm{~J} / \mathrm{m}^{2}\right.$ or $\left.10 \mathrm{~J} / \mathrm{m}^{2}\right)$, and then treated with/without $10 \mu \mathrm{M}$ of cisplatin for the indicated periods. Protein extracts were then harvested and examine by Western blotting using anti-PARP and anti-GAPDH antibodies. (B) SW480 and HT29 cells were first exposed to the indicated doses of UV-C $\left(0 \mathrm{~J} / \mathrm{m}^{2}\right.$ or $\left.10 \mathrm{~J} / \mathrm{m}^{2}\right)$, and then treated with/without $10 \mu \mathrm{M}$ of cisplatin for the indicated periods. They were then treated with Hoechst 33258 and were examined by fluorescence microscopy. The numbers of Hoechst33258-positive cells (apoptotic nuclei) from 5 randomly chosen fields ( $x$ 40) were counted, respectively. Bars designate SD of triplicate assay. The asterisks $\left(^{*}\right)$ indicate significant increase $(p<0.05)$ as compared to the corresponding controls, respectively.

tagged EGFR reappeared on the cell surface, thus suggesting that internalized EGFR recycled back to the cell membrane (Figure 5A, panels 8-10). However, the EGFR remained to be internalized when the cells were treated with the combination of cisplatin and UV-C (Figure 5A, panels 12-15).

To verify these results, we measured the amount of cell surface EGFR by enzyme-linked immunosorbent assay (ELISA). Whereas UV-C alone decreased the amount of cell surface EGFR within $0.5 \mathrm{~h}$ (Figure 5B, lane 3 ). However, they were gradually recovered $3 \mathrm{~h}$ after treatment with UV-C (Figure 5B, lanes 3, respectively). On the contrary, cell surface EGFR in the cells treated with the combination of cisplatin and UV-C remained to be decreased (Figure 5B, lanes 4, respectively). Taken together with our results obtained from fluorescence study, we strongly suggest that the treatment with cisplatin after UV-C exposure blocks the recycling of the EGFR which are internalized by UV-C.

\section{Discussion}

Platinum-containing anti-cancer drugs, including cisplatin, inhibit DNA replication [34,35] and RNA transcription [36], and induce cell cycle arrest at the G2-phase and apoptosis [27,37]. However, cisplatin at a higher dose concomitantly raises severe adverse effects, such as myelo-supression, nausea, anorexia, diarrhea and liver dysfunction. Therefore, many trials have made effort to minimize the dose of cisplatin in cancer patients. In the present study, we examined the combination effect of low dose cisplatin $(10 \mu \mathrm{M})$ and low dose UV-C $\left(10 \mathrm{~J} / \mathrm{m}^{2}\right)$ on human colorectal cancer cells, while we recently reported the potential availability of UV-C in these cells [26].

We herein demonstrated that the combination use synergistically inhibited the cell proliferation by BrdU assay (Figure 1A), flow cytometry (Figure 1B), Western blotting (Figure 2A) and colony formation assay (Figure 2B). We also unveiled that the cisplatin and 


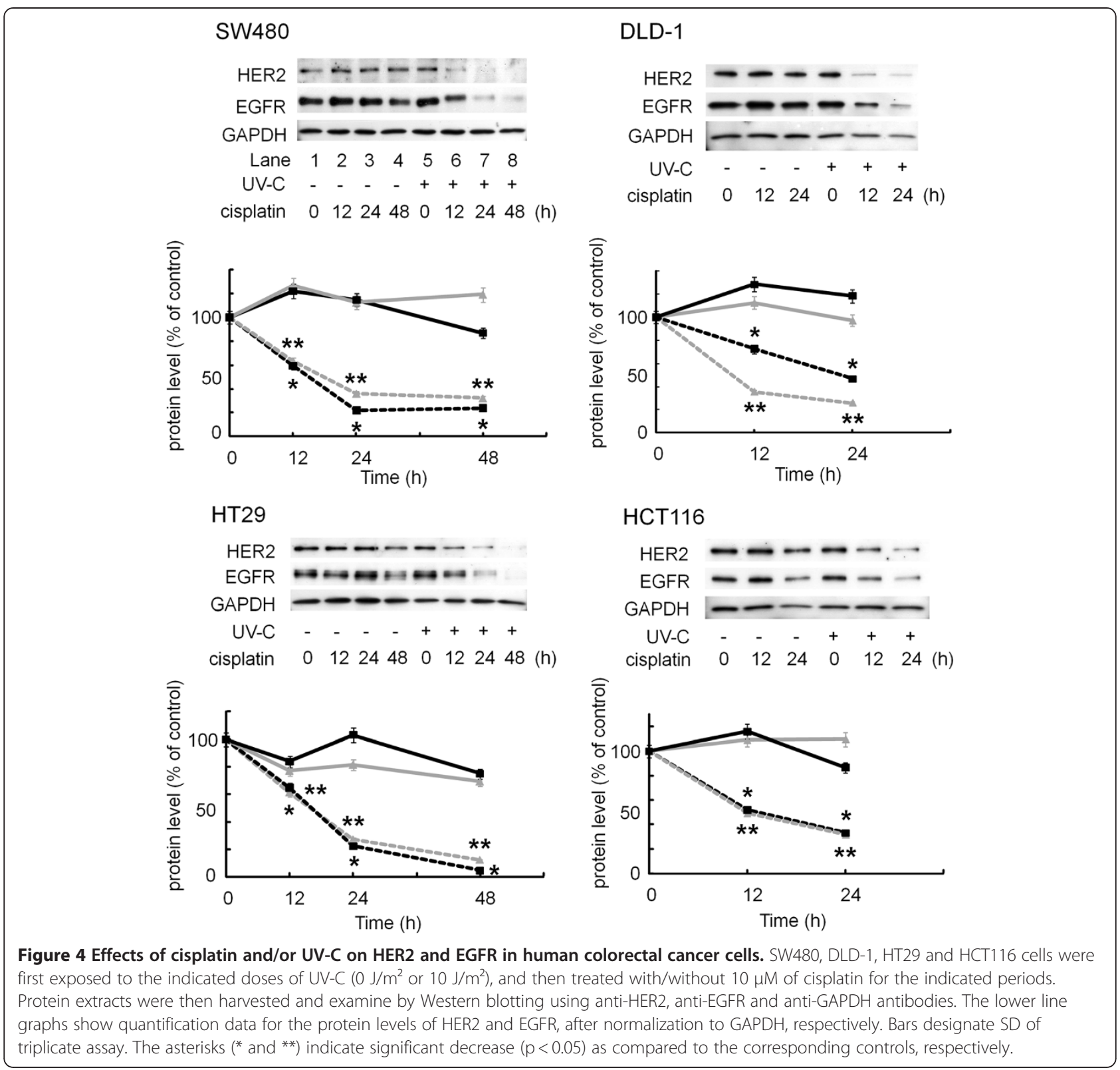

UV-C have synergistic effect on apoptosis, while cisplatin or UV-C alone had little effect (Figure 3). They were accompanied by downregulation of RTKs, such as EGFR and HER2 (Figure 4), both of which reportedly play a critical role in cell proliferation in many types of cancers including colorectal cancer $[7,38]$.

An anti-EGFR monoclonal antibody inhibits EGFR activation, resulting in the enhancement of the anti-cancer effect of cisplatin $[39,40]$. Indeed, chemotherapy with cetuximab or panitumumab, both of which are also antiEGFR monoclonal antibodies, can prolong survival period of colorectal cancer patients by nearly twentyfour months [41-43]. On the contrary, it has recently been reported that EGFR inhibition can protect EGFR from cisplatin-mediated phosphorylation and subsequent ubiquitination and degradation, indicating that treatment with an EGFR inhibitor before cisplatin would be antagonistic [13]. Thus, the efficacy of the combination of cisplatin and EGFR targeting drugs remains to be elucidated. In this study, low dose UV-C $\left(10 \mathrm{~J} / \mathrm{m}^{2}\right)$ induced EGFR internalization, but these receptors recycled back to the cell surface, whereas the combination use of cisplatin and UV-C induced persistent EGFR internalization (Figure 5). It has previously been reported that if cisplatin-bound EGFRs remain on the cell surface, they catalytically inhibit cell death [33]. Therefore, we speculate that pretreatment with UV-C helps cisplatin to induce degradation of EGFR, since 


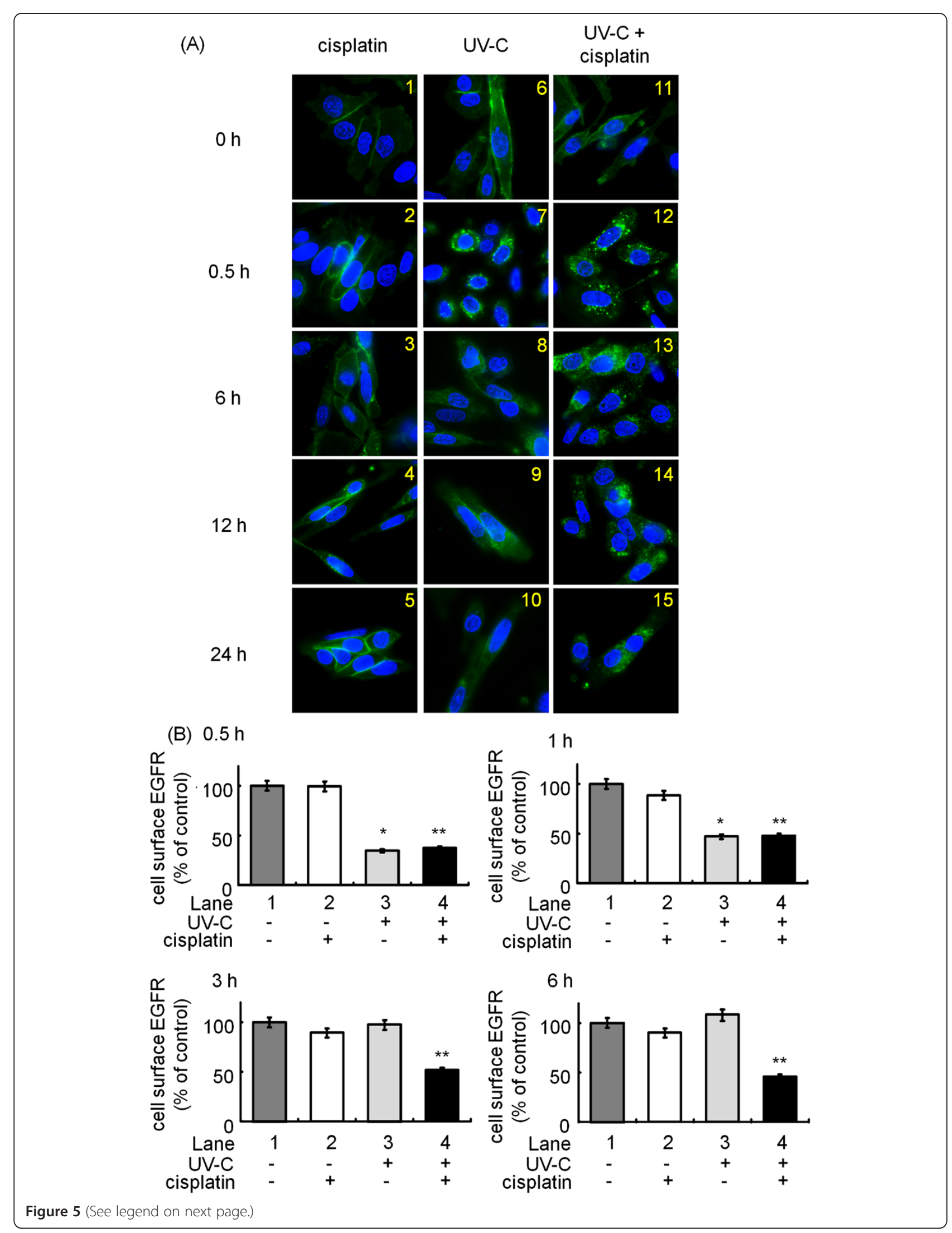


(See figure on previous page.)

Figure $\mathbf{5}$ (A) Effects of cisplatin and/or UV-C on the localization of EGFR in SW480 cells. SW480 cells were first labeled for 15 min at $37^{\circ} \mathrm{C}$ with anti-EGFR antibodies. They were then exposed to $10 \mathrm{~J} / \mathrm{m}^{2}$ of UV-C (panels 6-10 and 11-15, respectively) or not (panels $1-5$, respectively), followed by the treatment with (panels 1-5 and 11-15, respectively) or without (panels $6-10$, respectively) $10 \mu \mathrm{M}$ of cisplatin for the indicated periods at $37^{\circ} \mathrm{C}$. After fixation and permeabilization, the cells were stained with Alexa $488^{\circledR}$ conjugated anti-mouse secondary antibody for EGFR (green signal) and DAPI (blue signal) for $1 \mathrm{~h}$, and then examined by fluorescence microscope. (B) Effects of cisplatin and/or UV-C on the amount of cell surface EGFR in SW480 cells. SW480 cells were first labeled for 15 min at $37^{\circ} \mathrm{C}$ with an anti-EGFR antibody that recognizes the extracellular domain of the EGFR. They were then exposed to $10 \mathrm{~J} / \mathrm{m}^{2} \mathrm{UV}-\mathrm{C}$ (lanes 3 and 4) or not (lanes 1 and 2), followed by the treatment with (lanes 2 and 4) or without $10 \mu \mathrm{M}$ cisplatin (lanes 1 and 3) for the indicated periods at $37^{\circ} \mathrm{C}$. The amount of cell surface EGFR was then measured by ELISA. The asterisks $\left(*\right.$ and $\left.{ }^{* *}\right)$ indicate significant decrease $(p<0.05)$ with respect to the control (lane 1 , respectively). For additional details see Materials and methods.

UV-C alone caused EGFR internalization into the perinuclear area of the cells, where cisplatin might exert maximum effect on the donwregulation of EGFR (summarized in Figure 6). Nevertheless, further investigation is required to elucidate why UV-C causes EGFR internalization and why cisplatin induces EGFR degradation.

Regarding the mechanisms underlying EGFR downregulation, they involve several important phosphorylation sites in EGFR, including Tyr1045, a docking site for the ubiquitin ligase c-Cbl, and Ser1046/1047, which are required for EGFR desensitization in EGF-treated cells $[44,45]$. We recently found that (-)-epigallocatechin-3-gallate as well as heat shock protein 90 inhibitors cause down-regulation of the EGFR via phosphorylation at Ser1046/1047 through p38 MAPK in human cancer cells [46,47]. However, we did not observe the

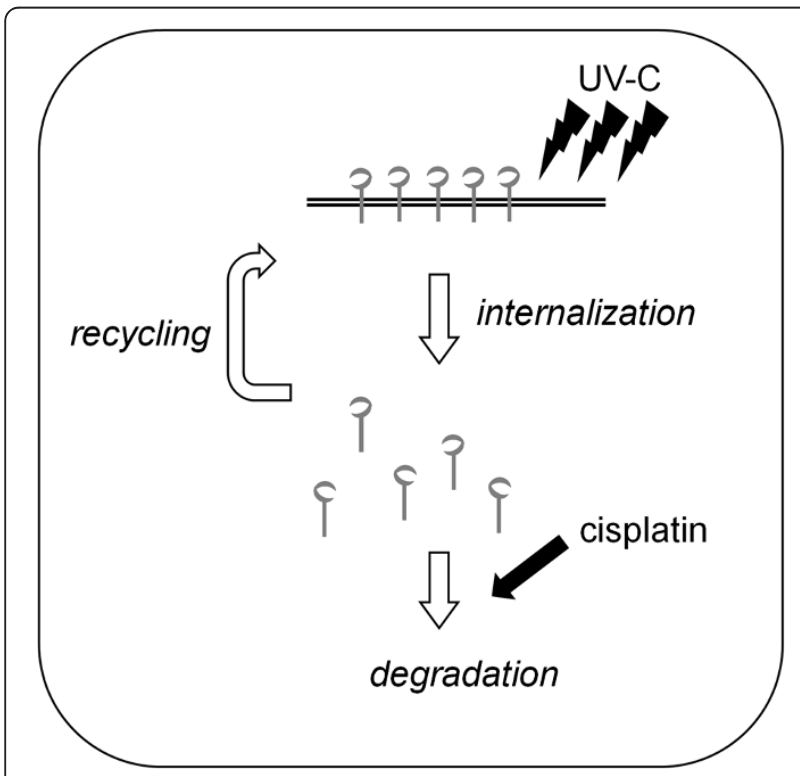

Figure 6 Schematic representation of the combination effect of cisplatin and UV-C in human colorectal cancer cells. After UV-C exposure even at a low dose, cell surface EGFR is internalized. With time the internalized EGFR by UV-C recycles back to the cell membrane, but cisplatin blocks this recycling and induces EGFR degradation, resulting in cell cycle arrest. phosphorylation of EGFR at these residues when the cells were treated with low dose cisplatin and/or low dose UV-C in colorectal cancer cells (data not shown). Therefore, it seems that EGFR degradation by the combination does not depend on Tyr1045 or Ser1046/1047. Moreover, it has previously reported that p38 MAPK plays an important role in $100 \mathrm{~J} / \mathrm{m}^{2} \mathrm{UV}$-induced EGFR internalization [33]. However in the present study, the combination did not influence the phosphorylation of p38 MAPK (data not shown). These results also suggest that the synergistic effect of cisplatin and UV-C also does not depend on p38 MAPK activation.

Initial platinum treatment is generally responsive, but the majority of cancer patients eventually relapse with cisplatin-resistance $[10,48]$. Several mechanisms of resistance to cisplatin are proposed; 1) reduced drug uptake, 2) increased drug inactivation, 3) increased DNA adduct repair, and 4) defective apoptotic response [10]. Importantly, a poor response of human cancers to cisplatin is associated with amplification and overexpression of HER2 found in some of breast and ovarian cancer patients $[10,48]$. Since we showed that the combination use of cisplatin and UV-C down-regulated HER2 (Figure 4), UV-C could alter the resistance to cisplatin in human colorectal cancer cells.

\section{Conclusions}

These results suggest that UV-C synergizes with cisplatin in the downregulation of receptor tyrosine kinases in human colorectal cancer cells. Our findings could provide a new aspect for the treatment of patients with colorectal cancer, although further investigation is required to develop devices that supply UV-C efficiently into human colorectal cancer, for example with endoscopic/laparoscopic approach.

\section{Materials and methods Materials}

Antibodies against total EGFR and glyceraldehyde-3phosphate dehydrogenase (GAPDH) were obtained from Santa Cruz Biotechnology (Santa Cruz, CA). Antibodies against total HER2, cyclin D1, phospho-retinoblastoma 
(Rb) and poly (ADP-ribose) polymerase (PARP) were purchased from Cell Signaling (Beverly, MA). Cisplatin was purchased from Sigma Aldrich (St. Louis, MO). ECL Western blot detection system was purchased from GE Healthcare (Buckinghamshire, UK). Cell Proliferation ELISA (BrdU) was obtained from Roche Diagnostics Co (Indianapolis, IN). Alexa Fluor $488^{\circledR}$ conjugated donkey anti-mouse IgG antibodies and 4',6diamidino-2-phenylindole (DAPI) were purchased from Invitrogen and Wako (Tokyo, Japan), respectively. p2'-(4-Hydroxyphenyl)-5-(4-methyl-1-piperazinyl)-2, 5'bi-1 H-benzimidazole, trihydrochloride (Hoechst 33258) solution was purchased from Dojindo (Kumamoto, Japan). PI/RNase Staining Buffer was obtained from Becton Dickinson (Franklin Lakes, NJ). Other materials and chemicals were obtained from commercial sources.

\section{Cell culture}

SW480 and HT29 human colorectal cancer cells, that were obtained from American Type Culture Collection (Manassas, VA), were grown in Dulbecco's modified Eagle's medium (DMEM) (Invitrogen, San Diego, CA), containing $10 \%$ fetal calf serum (FCS) with penicillin $(100 \mathrm{U} / \mathrm{ml})$ and streptomycin $(100 \mu \mathrm{g} / \mathrm{ml})$ in a humidified $5 \% \mathrm{CO}_{2}$ incubator at $37^{\circ} \mathrm{C}$. DLD-1 and $\mathrm{HCT} 116$ human colorectal cancer cells were from American Type Culture Collection (Manassas, VA) and grown in Roswell Park Memorial Institute 1640 (RPMI) (Invitrogen, San Diego, CA) as described above.

\section{UV-C exposure}

UV-C exposure of cells was performed in UV-C $500 \mathrm{UV}$ Crosslinker (8 W 254 nm UV lamp) (GE Healthcare), which creates CW light using 8 W 254 nm UV lamps. Fluorescent lamps without a phosphorescent coating emit UV with two peaks at $254 \mathrm{~nm}$ and $185 \mathrm{~nm}$ due to the peak emission of the mercury within the bulb. UV lamps used quartz (glass) block the $185 \mathrm{~nm}$ wavelength and emit only $254 \mathrm{~nm}$ UV. After aspiration of the growth medium, the cells were exposed to the indicated dose $\left(\mathrm{J} / \mathrm{m}^{2}=100 \mu \mathrm{J} / \mathrm{cm}^{2}\right)$ of UV-C in $5 \mathrm{sec}$, and then incubated for the indicated times.

\section{Cell proliferation assay}

BrdU incorporation was measured using cell Proliferation ELISA (BrdU). The cells $\left(7 \times 10^{3} /\right.$ well) were seeded onto 96-well plates and $48 \mathrm{~h}$ later, the cells were exposed to the indicated doses $\left(0\right.$ or $\left.10 \mathrm{~J} / \mathrm{m}^{2}\right)$ of UV-C, just after the aspiration of the growth medium. The cells were then incubated in DMEM or RPMI medium with $1 \%$ FCS and $10 \mu \mathrm{M}$ of cisplatin for $24 \mathrm{~h}$. They were then used for the assay according to the manufacturer's protocol. All assays were done at least three times.

\section{Cell cycle analysis}

Cell cycle analysis was done as described previously [7]. In brief, SW480 cells were exposed to UV-C, followed by the incubation in DMEM with/without $10 \mu \mathrm{M}$ of cisplatin for $96 \mathrm{~h}$. The cells were then harvested and stained with $500 \mu \mathrm{l}$ of PI/RNase staining buffer for $15 \mathrm{~min}$ at room temperature. They were finally analyzed by flow cytometry using a FACS Calibur instrument (Becton Dickinson); data were analyzed using the CELL Quest computer program (Becton Dickinson) as previously described. All data were obtained from at least three independent experiments.

\section{Colony formation assay}

Human colorectal cancer cells (SW480, DLD-1, HT29 and HCT116) were exposed to UV-C and then incubated in DMEM or RPMI medium and with/without $10 \mu \mathrm{M}$ of cisplatin. Twenty four $\mathrm{h}$ after treatment, the cells were trypsinized and the cells $\left(3 \times 10^{3}\right)$ were reseeded into fresh tissue culture dishes and incubated for 7 days. Fresh media were added at day 4. At day 7, the media were removed and the cells were fixed with $2 \mathrm{ml}$ of clonogenic reagent (50\% ethanol, 0.25\% 1,9-dimethylmethylene blue) for $45 \mathrm{~min}$. They were then washed with PBS twice and counted the blue colonies on 5 randomly chosen fields.

\section{Western blotting}

The cells were lysed in lysis buffer $[20 \mathrm{mM}$ Tris $/ \mathrm{HCl}$ (pH 7.5), $150 \mathrm{mM} \mathrm{NaCl}, 1 \mathrm{mM}$ EDTA, 1 mM EGTA, 1\% TritonX-100, $2.5 \mathrm{mM}$ sodium pyrophosphate, $50 \mathrm{mM}$ $\mathrm{NaF}, 50 \mathrm{mM}$ HEPES, $1 \mathrm{mM} \mathrm{Na} \mathrm{VO}_{4}$ and $2 \mathrm{mM}$ phenylmethylsulfonyl fluoride (PMSF)] and scraped from the Petri dishes. Protein extracts were examined by Western blot analysis as previously described $[49,50]$.

\section{Immunofluorescence microscopy studies}

Immunofluorescence microscopy studies were performed as described previously [46]. Live cells grown on coverslip-bottom dishes in DMEM were first exposed to the mouse anti-EGFR antibody that recognized the extracellular domain of EGFR for $15 \mathrm{~min}$ and then exposed to UV-C $\left(10 \mathrm{~J} / \mathrm{m}^{2}\right)$ and/or cisplatin $(10 \mu \mathrm{M})$ and incubated in DMEM for the indicated times $(0.5 \mathrm{~h}, 6 \mathrm{~h}$, $12 \mathrm{~h}$ and $24 \mathrm{~h}$ ) at $37^{\circ} \mathrm{C}$. They were then fixed with $4 \%$ paraformaldehyde for $10 \mathrm{~min}$ on ice and then exposed to $0.1 \%$ Triton $\mathrm{X}-100$ for $10 \mathrm{~min}$ to permeabilize the cell membrane. They were followed by exposure to Alexa Fluor $488^{\circledR}$ conjugated donkey anti-mouse IgG antibodies (green signal) and 4',6-diamidino-2-phenylindole (DAPI) for $1 \mathrm{~h}$. The cells were then examined by fluorescence microscopy, BIOREVO (BZ-9000) (Keyence, Tokyo, Japan) according to the manufacturer's protocol. 


\section{Quantification of cell surface EGFR by enzyme-linked immunosorbent assay (ELISA)}

Quantification of cell surface EGFR was performed as described previously [26]. In brief, SW480 cells were first exposed to the mouse anti-EGFR antibody in DMEM containing $1 \% \mathrm{BSA}$, for $15 \mathrm{~min}$ at $37^{\circ} \mathrm{C}$. The cells were then incubated for the indicated times in DMEM with/ without $10 \mu \mathrm{M}$ of cisplatin after exposure to UV-C, then fixed with $4 \%$ paraformaldehyde for $10 \mathrm{~min}$ on ice. After blocking with $1 \%$ BSA in PBS for $1 \mathrm{~h}$, the cells were exposed to an anti-mouse IgG, horseradish peroxidaselinked whole antibody (GE healthcare, Piscataway, NJ) for $1 \mathrm{~h}$ at room temperature, followed by washing four times with PBS containing 1\% BSA. Finally, the cells were exposed to $50 \mu \mathrm{l}$ of 1 -stepTM Ultra TMB-ELISA reagent (Pierce, Rockford, IL) for $5 \mathrm{~min}$ at room temperature. The absorbance of each sample at $450 \mathrm{~nm}$ was then measured.

\section{Hoechst 33258 staining}

Live cells grown on coverslip-bottom dishes were first exposed to UV-C $\left(10 \mathrm{~J} / \mathrm{m}^{2}\right)$ and/or cisplatin $(10 \mu \mathrm{M})$ for $72 \mathrm{~h}$ and then stained with Hoechst 33258 in DMEM without FCS for $1 \mathrm{~h}$ at $37^{\circ} \mathrm{C}$. They were then fixed with 4\% paraformaldehyde for $10 \mathrm{~min}$ on ice. The cells were then examined by fluorescence microscopy, as described above.

\section{Densitometric analysis}

The densitometric analysis was performed using scanner and image analysis software (Image J ver. $1.45 \mathrm{~g}$ ). The back ground subtracted signal intensity of each protein signal was normalized by the respective control signal. All data were obtained from at least three independent experiments.

\section{Statistical analysis}

The data were analyzed by ANOVA followed by Bonferroni method for multiple comparisons between the indicated pairs, and a $\mathrm{p}<0.05$ was considered significant.

\section{Additional file}

Additional file 1: Effect of $10 \mathrm{~J} / \mathrm{m}^{2}$ UV-C on HER2, EGFR, phospho$\mathrm{Rb}$ and cyclin D1 in human colorectal cancer cells. SW480, DLD-1, HT29 and HCT116 cells were exposed to $10 \mathrm{~J} / \mathrm{m}^{2}$ of UV-C and then treated for the indicated periods. Protein extracts were then harvested and examine by Western blotting using anti-HER2, anti-EGFR, antiphospho-Rb, anti-cyclin D1 and anti-GAPDH antibodies.

\section{Abbreviations}

UV-C: Ultra-violet-C; RTKs: Receptor tyrosine kinases; EGF: Epidermal growth factor; EGFR: EGF receptor; HER2: Human epidermal growth factor receptor-2; GAPDH: Glyceraldehyde-3-phosphate dehydrogenase; Rb: Retinoblastoma protein; PARP: Poly (ADP-ribose) polymerase; MAPK: Mitogen-activated protein kinase; GSK: Glycogen synthase kinas; DMEM: Dulbecco's modified
Eagle's medium; RPMI: Roswell Park Memorial Institute 1640; FCS: Fetal calf serum; PBS: Phosphate buffered saline; BrdU: Bromodeoxyuridine (5-bromo2'-deoxyuridine); ELISA: Enzyme-linked immunosorbent assay; DAPI: 4',6diamidino-2-phenylindole; Hoechst 33258: p2'-(4-Hydroxyphenyl)-5-(4methyl-1-piperazinyl)-2, 5'-bi-1H-benzimidazole, trihydrochloride.

\section{Competing interests}

The authors declare that they have no competing interests.

\section{Authors' contributions}

SA designed the research studies; SA, JK, TY, MN, TO, MS, TY and MI carried out the molecular biological studies; SA, IY, OK and HM analyzed and interpreted the data; JK wrote the draft of the manuscript. All authors read and approved the final manuscript.

\section{Acknowledgements}

We are very grateful to Ms. Yoko Kawamura for her skillful technical assistance. This work was supported in part by Grant-in-Aid for Scientific Research (22790639 to S.A) from the Ministry of Education, Science, Sports and Culture of Japan.

\section{Author details}

${ }^{1}$ Departments of Gastroenterology, Gifu University Graduate School of Medicine, Gifu 501-1194, Japan. ${ }^{2}$ Departments of Pharmacology, Gifu University Graduate School of Medicine, Gifu 501-1194, Japan. ${ }^{3} 1-1$ Yanagido, Gifu 501-1194, Japan.

Received: 1 February 2012 Accepted: 24 April 2012

Published: 12 July 2012

\section{References}

1. Hynes NE, Horsch K, Olayioye MA, Badache A: The ErbB receptor tyrosine family as signal integrators. Endocr Relat Cancer 2001, 8:151-159.

2. Kuan CT, Wikstrand CJ, Bigner DD: EGF mutant receptor vill as a molecular target in cancer therapy. Endocr Relat Cancer 2001, 8:83-96.

3. Zandi R, Larsen AB, Andersen P, Stockhausen MT, Poulsen HS: Mechanisms for oncogenic activation of the epidermal growth factor receptor. Cell Signal 2007, 19:2013-2023.

4. Nakashima M, Adachi S, Yasuda I, Yamauchi T, Kozawa O, Moriwaki H: Rho-kinase regulates negatively the epidermal growth factor-stimulated colon cancer cell proliferation. Int J Oncol 2010, 36:585-592.

5. Borg A, Linell F, Idvall I, Johansson S, Sigurdsson H, Ferno M, Killander D: HER2/neu amplification and comedo type breast carcinoma. Lancet 1989, 1:1268-1269.

6. Shepard HM, Lewis GD, Sarup JC, Fendly BM, Maneval D, Mordenti J, Figari I, Kotts CE, Palladino MA Jr, Ullrich A, et al: Monoclonal antibody therapy of human cancer: taking the HER2 protooncogene to the clinic. J Clin Immunol 1991, 11:117-127.

7. Shimizu M, Deguchi A, Lim JT, Moriwaki H, Kopelovich L, Weinstein IB: (-)-Epigallocatechin gallate and polyphenon $\mathrm{E}$ inhibit growth and activation of the epidermal growth factor receptor and human epidermal growth factor receptor-2 signaling pathways in human colon cancer cells. Clin Cancer Res 2005, 11:2735-2746.

8. Feng FY, Varambally S, Tomlins SA, Chun PY, Lopez CA, Li X, Davis MA, Chinnaiyan AM, Lawrence TS, Nyati MK: Role of epidermal growth factor receptor degradation in gemcitabine-mediated cytotoxicity. Oncogene 2007, 26:3431-3439.

9. Masuda M, Suzui M, Weinstein IB: Effects of epigallocatechin-3-gallate on growth, epidermal growth factor receptor signaling pathways, gene expression, and chemosensitivity in human head and neck squamous cell carcinoma cell lines. Clin Cancer Res 2001, 7:4220-4229.

10. Siddik $\mathrm{ZH}$ : Cisplatin: mode of cytotoxic action and molecular basis of resistance. Oncogene 2003, 22:7265-7279.

11. Parker LJ, Italiano LC, Morton CJ, Hancock NC, Ascher DB, Aitken JB, Harris $\mathrm{HH}$, Campomanes P, Rothlisberger U, De Luca A, et al: Studies of glutathione transferase P1-1 bound to a platinum(IV)-based anticancer compound reveal the molecular basis of its activation. Chemistry 2011, 17:7806-7816.

12. Muscella A, Urso L, Calabriso N, Vetrugno C, Fanizzi FP, Storelli C, Marsigliante S: Functions of epidermal growth factor receptor in cisplatin response of thyroid cells. Biochem Pharmacol 2009, 77:979-992. 
13. Ahsan A, Hiniker SM, Ramanand SG, Nyati S, Hegde A, Helman A, Menawat R, Bhojani MS, Lawrence TS, Nyati MK: Role of epidermal growth factor receptor degradation in cisplatin-induced cytotoxicity in head and neck cancer. Cancer Res 2010, 70:2862-2869.

14. Winograd-Katz SE, Levitzki A: Cisplatin induces PKB/Akt activation and p38 (MAPK) phosphorylation of the EGF receptor. Oncogene 2006, 25:7381-7390

15. Benhar M, Dalyot I, Engelberg D, Levitzki A: Enhanced ROS production in oncogenically transformed cells potentiates c-Jun N-terminal kinase and p38 mitogen-activated protein kinase activation and sensitization to genotoxic stress. Mol Cell Biol 2001, 21:6913-6926.

16. Latonen $L$, Laiho M: Cellular UV damage responses-functions of tumor suppressor p53. Biochim Biophys Acta 2005, 1755:71-89.

17. Olsen BB, Neves-Petersen MT, Klitgaard S, Issinger OG, Petersen SB: UV light blocks EGFR signalling in human cancer cell lines. Int J Oncol 2007, 30:181-185.

18. Kim SC, Park SS, Lee YJ: Effect of UV irradiation on colorectal cancer cells with acquired TRAIL resistance. J Cell Biochem 2008, 104:1172-1180.

19. Petersen MT, Jonson PH, Petersen SB: Amino acid neighbours and detailed conformational analysis of cysteines in proteins. Protein Eng 1999, 12:535-548.

20. Prompers JJ, Hilbers CW, Pepermans HA: Tryptophan mediated photoreduction of disulfide bond causes unusual fluorescence behaviour of Fusarium solani pisi cutinase. FEBS Lett 1999, 456:409-416.

21. Neves-Petersen MT, Gryczynski Z, Lakowicz J, Fojan P, Pedersen S, Petersen E, Bjorn Petersen S: High probability of disrupting a disulphide bridge mediated by an endogenous excited tryptophan residue. Protein SCi 2002, 11:588-600.

22. Vanhooren A, Devreese B, Vanhee K, Van Beeumen J, Hanssens I: Photoexcitation of tryptophan groups induces reduction of two disulfide bonds in goat alpha-lactalbumin. Biochemistry 2002, 41:11035-11043.

23. Neves-Petersen MT, Snabe T, Klitgaard S, Duroux M, Petersen SB: Photonic activation of disulfide bridges achieves oriented protein immobilization on biosensor surfaces. Protein Sci 2006, 15:343-351.

24. Neves-Petersen MT, Duroux M, Skovsen E, Duroux L, Petersen SB: Printing novel molecular architectures with micrometer resolution using light. J Nanosci Nanotechnol 2009, 9:3372-3381.

25. Neves-Petersen MT, Klitgaard S, Pascher T, Skovsen E, Polivka T, Yartsev A, Sundstrom V, Petersen SB: Flash photolysis of cutinase: identification and decay kinetics of transient intermediates formed upon UV excitation of aromatic residues. Biophys J 2009, 97:211-226.

26. Adachi S, Yasuda I, Nakashima M, Yamauchi T, Kawaguchi J, Shimizu M, Itani M, Nakamura M, Nishii Y, Yoshioka T, et al: Ultraviolet irradiation can induce evasion of colon cancer cells from stimulation of epidermal growth factor. J Biol Chem 2011, 286:26178-26187.

27. Sorenson CM, Barry MA, Eastman A: Analysis of events associated with cell cycle arrest at G2 phase and cell death induced by cisplatin. J Natl Cancer Inst 1990, 82:749-755.

28. Sherr CJ: Cancer cell cycles. Science 1996, 274:1672-1677.

29. Hoffman RM: In vitro sensitivity assays in cancer: a review, analysis, and prognosis. J Clin Lab Anal 1991, 5:133-143.

30. Boulares AH, Yakovlev AG, Ivanova V, Stoica BA, Wang G, Iyer S, Smulson M: Role of poly(ADP-ribose) polymerase (PARP) cleavage in apoptosis. Caspase 3-resistant PARP mutant increases rates of apoptosis in transfected cells. J Biol Chem 1999, 274:22932-22940.

31. Kapitanovic S, Radosevic S, Kapitanovic M, Andelinovic S, Ferencic Z, Tavassoli M, Primorac D, Sonicki Z, Spaventi S, Pavelic K, Spaventi R: The expression of 185 (HER-2/neu) correlates with the stage of disease and survival in colorectal cancer. Gastroenterology 1997, 112:1103-1113.

32. Mendelsohn J, Baselga J: The EGF receptor family as targets for cancer therapy. Oncogene 2000, 19:6550-6565.

33. Zwang $Y$, Yarden Y: p38 MAP kinase mediates stress-induced internalization of EGFR: implications for cancer chemotherapy. Embo $J$ 2006, 25:4195-4206.

34. Ciccarelli RB, Solomon MJ, Varshavsky A, Lippard SJ: In vivo effects of cisand trans-diamminedichloroplatinum(II) on SV40 chromosomes: differential repair, DNA-protein cross-linking, and inhibition of replication. Biochemistry 1985, 24:7533-7540.

35. Salles B, Butour JL, Lesca C, Macquet JP: cis- $\mathrm{Pt}(\mathrm{NH} 3) 2 \mathrm{Cl} 2$ and trans- $\mathrm{Pt}(\mathrm{NH} 3)$ $2 \mathrm{Cl} 2$ inhibit DNA synthesis in cultured L1210 leukemia cells. Biochem Biophys Res Commun 1983, 112:555-563.
36. Mello JA, Lippard SJ, Essigmann JM: DNA adducts of cis-diamminedichloroplatinum(II) and its trans isomer inhibit RNA polymerase II differentially in vivo. Biochemistry 1995, 34:14783-14791.

37. Sorenson CM, Eastman A: Influence of cis-diamminedichloroplatinum(II) on DNA synthesis and cell cycle progression in excision repair proficient and deficient Chinese hamster ovary cells. Cancer Res 1988, 48:6703-6707.

38. Nakashima M, Adachi S, Yasuda I, Yamauchi T, Kawaguchi J, Hanamatsu T, Yoshioka T, Okano Y, Hirose Y, Kozawa O, Moriwaki H: Inhibition of Rhoassociated coiled-coil containing protein kinase enhances the activation of epidermal growth factor receptor in pancreatic cancer cells. Mol Cancer 2011, 10:79.

39. Benhar M, Engelberg D, Levitzki A: Cisplatin-induced activation of the EGF receptor. Oncogene 2002, 21:8723-8731.

40. Yoshida T, Okamoto I, Iwasa T, Fukuoka M, Nakagawa K: The anti-EGFR monoclonal antibody blocks cisplatin-induced activation of EGFR signaling mediated by HB-EGF. FEBS Lett 2008, 582:4125-4130.

41. Douillard JY, Siena S, Cassidy J, Tabernero J, Burkes R, Barugel M, Humblet $Y$, Bodoky G, Cunningham D, Jassem J, et al: Randomized, phase III trial of panitumumab with infusional fluorouracil, leucovorin, and oxaliplatin (FOLFOX4) versus FOLFOX4 alone as first-line treatment in patients with previously untreated metastatic colorectal cancer: the PRIME study. J Clin Oncol 2010, 28:4697-4705.

42. Siena S, Peeters M, Van Cutsem E, Humblet $Y$, Conte $P$, Bajetta $E$, Comandini D, Bodoky G, Van Hazel G, Salek T, et al: Association of progression-free survival with patient-reported outcomes and survival: results from a randomised phase 3 trial of panitumumab. Br J Cancer 2007, 97:1469-1474

43. Amado RG, Wolf M, Peeters M, Van Cutsem E, Siena S, Freeman DJ, Juan T, Sikorski R, Suggs S, Radinsky R, et al: Wild-type KRAS is required for panitumumab efficacy in patients with metastatic colorectal cancer J Clin Oncol 2008, 26:1626-1634.

44. Countaway JL, Nairn AC, Davis RJ: Mechanism of desensitization of the epidermal growth factor receptor protein-tyrosine kinase. J Biol Chem 1992, 267:1129-1140.

45. Theroux SJ, Latour DA, Stanley K, Raden DL, Davis RJ: Signal transduction by the epidermal growth factor receptor is attenuated by a $\mathrm{COOH}$-terminal domain serine phosphorylation site. J Biol Chem 1992, 267:16620-16626.

46. Adachi S, Shimizu M, Shirakami Y, Yamauchi J, Natsume H, MatsushimaNishiwaki R, To S, Weinstein IB, Moriwaki H, Kozawa O: (-)-Epigallocatechin gallate downregulates EGF receptor via phosphorylation at Ser1046/ 1047 by p38 MAPK in colon cancer cells. Carcinogenesis 2009, 30:1544-1552

47. Adachi S, Yasuda I, Nakashima M, Yamauchi T, Yamauchi J, Natsume H, Moriwaki H, Kozawa O: HSP90 inhibitors induce desensitization of EGF receptor via p38 MAPK-mediated phosphorylation at Ser1046/1047 in human pancreatic cancer cells. Oncol Rep 2010, 23:1709-1714.

48. Kartalou M, Essigmann JM: Mechanisms of resistance to cisplatin. Mutat Res 2001, 478:23-43.

49. Adachi S, Nagao T, Ingolfsson HI, Maxfield FR, Andersen OS, Kopelovich L, Weinstein IB: The inhibitory effect of (-)-epigallocatechin gallate on activation of the epidermal growth factor receptor is associated with altered lipid order in HT29 colon cancer cells. Cancer Res 2007, 67:6493-6501.

50. Adachi S, Nagao T, To S, Joe AK, Shimizu M, Matsushima-Nishiwaki R, Kozawa O, Moriwaki H, Maxfield FR, Weinstein IB: (-)-Epigallocatechin gallate causes internalization of the epidermal growth factor receptor in human colon cancer cells. Carcinogenesis 2008, 29:1986-1993.

doi:10.1186/1476-4598-11-45

Cite this article as: Kawaguchi et al:: Cisplatin and ultra-violet-C synergistically down-regulate receptor tyrosine kinases in human colorectal cancer cells. Molecular Cancer 2012 11:45. 